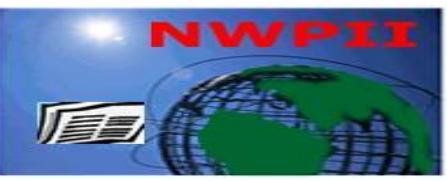

American Journal of Biomedical Sciences

ISSN: 1937-9080

nwpii.com/ajbms

\title{
Effect of Obestatin on Gastric Acid Secretion and Mucin Expression in Normal and Streptozoocin Induced Diabetic Rats
}

\begin{abstract}
Abeer A. Saeed MD and Reham H. Ibrahim MD
Physiology Department, Faculty of Medicine, Zagazig University, Egypt

*Corresponding Author

Dr. Reham Hassan Ibrahim

Physiology Department, Faculty of Medicine

Zagazig University

Egypt

Email: phisiology_lover_4@yahoo.com

Received:28 November 2018; | Revised:27 December 2018; $\mid$ Accepted:18 March 2019

Abstract

Background: Obestatin is a peptide hormone derived from the same peptide precursor as ghrelin, it regulates food intake and gastric motility, however, to date, no studies conducted about the effects of obestatin on gastric acid secretion and gastric mucin expression. Aim: investigate effects of obestatin on gastric acid secretion and mucin expression in normal and streptozoocin (STZ) induced diabetic male rats. Material and Methods: 32 adult male albino rats were divided into group I (normal) and group II STZ induced diabetic rats, each group further subdivided into two equal subgroups: group a (received intraperitoneal (ip) saline daily for 21 days) and group b (daily received ip obestatin "10 nmol/kg" for 21 days). In all groups, gastric secretion was collected, then total acid output, ghrelin and volume of gastric secretion were measured, real time polymerase chain reaction (PCR) for gastric mucin (MUC5AC) and gastric H+$\mathrm{K}+$-ATPase $\alpha$-subunit gene expression were measured, blood samples were obtained for insulin and glucose measurement. Results: in both normal and diabetic rats, obestatin increased total acid output, ghrelin, volume of gastric secretion, gastric H+-K+-ATPase $\alpha$-subunit and MUC5AC gene expression. There was none significant change in blood glucose and insulin in normal rats, while significant increase in insulin level and significant decrease in blood glucose in STZ induced diabetic rats. Conclusion: obestatin on chronic run increased gastric acidity, ghrelin and volume of gastric secretion in normal and diabetic rats, obestatin can be considered as gastro- protective agent as it increased gastric mucin in normal and diabetic rats.
\end{abstract}

Keywords: Obestatin, Gastric secretion, Acid, Diabetes, Ghrelin, H+-K+-ATPase

\section{Introduction}

Obestatin is a peptide hormone formed of 23amino-acid, it is mainly produced in the gastrointestinal tract and is derived from the posttranslational cleavage of the same peptide precursor as ghrelin ${ }^{[1]}$.Obestatin regulate metabolic function at the central and the peripheral levels, which includes regulation of food intake, gastric emptying with controversial results ${ }^{[2-4]}$, pancreatic, 
adipocyte, cardiac function as well as cell proliferation $^{[1,5-7]}$

It is worth saying that both the glucagon-like peptide-1 receptor (GLP1R), as well as the orphan G protein-coupled receptor 39 (GPR39) ,can be activated by obestatin. In addition, obestatin has been shown to compete with ghrelin's binding at the growth hormone secretegogus receptor(GHS-R) in pancreatic $\beta$-cell lines ${ }^{[1,8,9]}$, it can also be hypothesized that the pharmacological interaction between both peptides are mediated through the GHS-R. ${ }^{[5]}$. Obestatin is found in the gastrointestinal (GI) tract, within the A-like cells and oxyntic glands of the gastric mucosa and cholinergic neurons of the myenteric plexus, where it is co-localized with its precursor peptide, preproghrelin ${ }^{[10,11]}$, this may indicate that obestatin may has local autocrine/paracrine roles in gastric mucosa, moreover, in addition, obestatin binding to GPR39 has been demonstrated in gastric mucosa ${ }^{[1,12]}$, as intra-peritoneal injection of obestatin increased cfos staining in the nuclei of gastric mucosa ${ }^{[1]}$, these data suggest a possible effect of obestatin on gastric secretion.

In diabetic conditions, there is decrease in gastric acid secretion due to autonomic neuropathy [13], in addition, there is necrosis of gastric mucosal cells and decrease in gastric mucin (MUC) which secreted by the epithelial cells of the gastrointestinal mucosal cells that form a dynamic and interactive mucosal defense system on the gastrointestinal mucosal surface ${ }^{[14-16]}$.

It is interesting that obestatin has a promising role in improvement of diabetes mellitus symptoms $[17,18]$

Aim of the work: From the above data, the present study aimed to investigate the role of chronic obestatin administration on gastric secretion in normal and streptozotocin (STZ) induced diabetic rat model.

\section{Materials and Methods}

Groups of animals: Forty five adult male Wistar albino rats weighing 180-220g supplied from faculty of Veterinary Medicine, Zagazig University, were enrolled in the present study. All animals received care according to the guide and ethical regulations for the care and use of laboratory animals according to Institute of Laboratory Animal Resources $^{[19]}$, the animals were housed in plastic cages under controlled hygienic conditions with an ambient temperature $\left(22 \pm 2^{\circ} \mathrm{C}\right)$ and a 12 hours lightcycle. All animals were subjected to 7 days period for acclimatization. Rats were divided into two main groups: Group I (normal $n=16$ ) which was subdivided into 2 equal subgroups: Subgroup (1a) Each rat received intra-peritoneal (ip) injection of $0.5 \mathrm{ml}$ saline daily for 3 weeks. Subgroup (Ib) (obestatin-treated normal group): Each rat received ip daily dose of obestatin (1nmol/ 100gm) (Sigma Aldrich Co.-USA) for 3 weeks [20] Group II (diabetic $n=29$ ): to induce diabetes, for every rat ip single injection of freshly prepared solution of streptozotocin (Sigma Aldrich Co.-USA) $50 \mathrm{mg} / \mathrm{kg}$ dissolved in $0.2 \mathrm{mmol} / \mathrm{L}$ sodium citrate, at $\mathrm{PH}$ $4.5^{[21]}, 0.1-0.2 \mathrm{ukg}$ of insulin were given to rats per day to prevent ketosis and reduce mortality without making blood glucose level normal ${ }^{[22]}$ (10 rats died and 16 with high blood glucose levels were selected). Rats were ready for the experiment after development of gastric neuropathy three weeks after induction of diabetes ${ }^{[23]}$, It was subdivided into 2 equal subgroups (subgroup II a) each rat received ip injection of $0.5 \mathrm{ml}$ of saline daily for 3 weeks. (Subgroup II b) (obestatin-treated diabetic group): Each rat received ip daily dose of obestatin (1nmol/ 100gm) for 3 weeks ${ }^{[20]}$.

Methods: Collection of gastric secretion: At day 21 of experiment rats were fasted for 24 hours, rats was anaesthetized, using ether, a midline abdominal incision was performed, the pyloric portion of the stomach was gently mobilized and carefully ligated with a silk ligature around the pyloric sphincter taking care not to interfere with gastric blood supply .Abdominal incision was sutured and the animals were allowed to recover from anesthesia, collection of gastric juice was done after 1 hour of pylorus ligation ${ }^{[24]}$. Gastric juice from each animal was centrifuged to remove any solid debris and the volume of the supernatant was measured by measuring pipettes, gastric acid output was determined by titration of samples with $0.1 \mathrm{~N}$ $\mathrm{NaOH}$ to $\mathrm{pH} 7.0$ using phenolphthalein $(2 \%)$ as an indicator ${ }^{[25]}$.Acid output was calculated by multiplying the volume of gastric juice by the acid 
concentration $^{[26]}$. Ghrelin level was measured by the method of Kojima et al. ${ }^{[27]}$.

Gene expression of MUC5ac and $\mathrm{H}+-\mathrm{K}+-$ ATPase $\alpha$-subunit by real time PCR according to Wallace et al. ${ }^{[28]}$

The stomachs of animals were removed, opened along the greater curvature, rinsed with physiological saline, and pinned out in ice-cold saline, one hundred milligrams of gastric mucosal tissues were excised, snap-frozen in liquid nitrogen, and stored at $-80^{\circ} \mathrm{C}$ until required for processing. RNA isolation was performed using TRIzol (Invitrogen) according to the manufacturer's recommendations. RNA was DNase treated prior to cDNA synthesis using the iScript TM cDNA synthesis kit (BioRad). Real-time PCR amplification and analysis were performed using SYBR Green Master Mix (Applied Biosystems) in a Primer sequences that were synthesized by (MWGBiotech, Germany) as follows:

MUC-5AC

Forward primer

5--

CAACTGTCCGCAGGGCCAGG--3,

Reverse primer 5--ATGCTGT-
CCCCGCAGTTGCC--3.

$\mathrm{H}+\mathrm{K}+\mathrm{-ATPase} \alpha$-subunit

Forward primer: 5' - TAT GAA TTG TAC TCA GTG GA-3'

Reverse primer: 5-TGG TCT GGT ACT TCT GCT-3'

Amplification conditions were: incubation at $95^{\circ} \mathrm{C}$ for $10 \mathrm{~min}, 40$ two-step cycles with $15 \mathrm{~s}$ at $95^{\circ}$

$\mathrm{C}$ for denaturation, and annealing-extension at $60^{\circ} \mathrm{C}$ for $1 \mathrm{~min}$.

Relative expression of studied genes mRNA was normalized with control gene (beta actin which was used as the control housekeeping gene

Beta actin

Forward primer :5'--

GGTCGGTGTGAACGGATTTGG -3

Reverse primer

ATGTAGGCCATGAGGTCCACC-3.
Blood sampling: samples were obtained from all rats by scarification, serum was separated by centrifugation of blood at $3000 \mathrm{rpm}$ for 15 minutes and examined for: Serum glucose level: by the method of Tietz et al. ${ }^{[29]}$ using glucose enzymatic (GOD-PAP)-liquizyme Kits (Biotechnology, Egypt). Serum insulin level: according to Temple et al. ${ }^{[30]}$, by a solid phase enzyme amplified sensitivity immunoassay.

STATISTICAL ANALYSIS: Data were expressed as mean SD for quantitative variables and statistically analyzed by using SPSS program (version 18 for windows) (SPSS Inc. Chicago, IL, USA). One way analysis of variance (ANOVA) was done followed by LSD test to compare means of the different groups. $\mathrm{P}$ value $<0.05$ was considered statistically significant.

\section{Results}

Table 1 showed the effect of obestatin administration on gastric total acid output, ghrelin level and volume of gastric secretion:

.In subgroup Ib (normal obestatin treated) there was significant increase in ghrelin level, total acid output, volume of gastric secretion in comparison with that of Subgroup Ia (normal control) (P < 0.05).

In Subgroup IIa (diabetic control) there was significant decrease in ghrelin level, total acid output $(\mathrm{P}<0.001)$, in comparison with that of Subgroup Ia and $\mathrm{Ib}$, significant decrease in volume of gastric secretion $(\mathrm{P}<0.05)$ in comparison with that of Subgroup Ia and Ib.

In Subgroup IIb (diabetic obestatin treated) there was significant increase in ghrelin level, total acid output, volume of gastric secretion in comparison with that of subgroup IIa $(\mathrm{P}<0.05)$, while there was significant decrease in ghrelin level, total acid output in comparison with that of subgroup $\operatorname{Ia}(\mathrm{P}<0.05)$ and subgroup $\mathrm{Ib}(\mathrm{P}<0.001)$, significant decrease in volume of gastric secretion $(\mathrm{P}<0.05)$ in comparison with that of subgroup Ib.

In addition, In subgroup Ia, subgroup Ib and Subgroup IIb there was significant positive correlation between ghrelin and total acid output. 
Table 1: Effect of obestatin administration on ghrelin level, acidity and volume of gastric secretion in all studied groups

\begin{tabular}{|c|c|c|c|c|}
\hline & $\begin{array}{l}\text { GROUP I } \\
\text { (NORMAL) }\end{array}$ & & $\begin{array}{l}\text { GROUP II } \\
\text { (DIABETIC) }\end{array}$ & \\
\hline $\mathrm{s}$ & $\begin{array}{l}\text { Subgroup Ia (normal } \\
\text { control ) }\end{array}$ & $\begin{array}{l}\text { Subgroup Ib (normal } \\
\text { obestatin treated) }\end{array}$ & $\begin{array}{l}\text { Subgroup IIa } \\
\text { (Diabetic control) }\end{array}$ & $\begin{array}{l}\text { Subgroup IIb (Diabetic } \\
\text { obestatin treated) }\end{array}$ \\
\hline Ghrelin(pg\ml) & $59.9 \pm 5.4$ & $69.1 \pm 3.4 \mathrm{a}^{*}$ & $40.3 \pm 1.2 \mathrm{a} \mathrm{b} * * *$ & $51.7 \pm 3.4 \mathrm{a} \mathrm{c} * \mathrm{~b} * * *$ \\
\hline $\begin{array}{l}\text { Total acid output } \\
\text { (mEq / L /1 hour) }\end{array}$ & $\begin{array}{l}18 \pm 1.9 \\
\mathrm{r}=0.93^{* *}\end{array}$ & $\begin{array}{l}22.3 \pm 2.6 \mathrm{a} * \\
\mathrm{r}=0.91 * *\end{array}$ & $\begin{array}{l}12 \pm 2.3 \mathrm{a} \mathrm{b} * * * \\
\mathrm{r}=0.56\end{array}$ & $\begin{array}{l}15.9 \pm 6.3 \text { a c } * b * * * \\
\mathrm{r}=0.8 *\end{array}$ \\
\hline $\begin{array}{l}\text { Volume } \\
\text { (ml/ } 100 \mathrm{gm} / 1 \text { hour) }\end{array}$ & $\begin{array}{l}1.2 \pm 0.1 \\
\mathrm{r}=0.61\end{array}$ & $\begin{array}{l}1.9 \pm 0.25 \mathrm{a} * \\
\mathrm{r}=0.58\end{array}$ & $\begin{array}{l}0.88 \pm 0.3 \mathrm{ab}^{*} \\
\mathrm{r}=0.51\end{array}$ & $\begin{array}{l}0.99 \pm 0.24 \mathrm{~b} * \mathrm{c} * \\
\mathrm{r}=0.39\end{array}$ \\
\hline
\end{tabular}

$\left({ }^{a}\right)=$ significant vs. group Ia, $\left({ }^{b}\right)=$ significant vs. group $\mathrm{Ib},\left(^{\mathrm{c}}\right)=$ significant vs. group IIa, $\mathrm{r}=$ correlation with ghrelin

Table 2 showed the effect of obestatin administration on gene expression of MUC5AC and $\mathrm{H}+\mathrm{K}+\mathrm{-ATPase} \alpha$-subunit by real time PCR:

In subgroup $\mathrm{Ib}$, there was a significant increase in MUC5AC and $\mathrm{H}+\mathrm{K}+\mathrm{ATPase} \alpha$-subunit gene expression $(\mathrm{P}<0.05)$ in comparison to subgroup Ia. In subgroup IIa, there was a significant decrease in mentioned parameters $(\mathrm{P}<0.05)$, in comparison to both subgroup Ia and Ib. In subgroup IIb, there was a significant increase in mentioned parameters $(\mathrm{P}<0.05)$ in comparison to subgroup IIa, however, there was a significant decrease in mentioned parameters $(\mathrm{P}<0.05)$, in comparison to subgroup $\mathrm{Ib}$.

Table 2: Effect of obestatin administration on gene expression of MUC5AC and H+-K+-ATPase $\alpha$-subunit by real time PCR in all groups

\begin{tabular}{|c|l|l|l|l|}
\hline & $\begin{array}{l}\text { GROUP I } \\
\text { (NORMAL) }\end{array}$ & $\begin{array}{l}\text { GROUP II } \\
\text { (DIABETIC) }\end{array}$ \\
\hline & $\begin{array}{l}\text { Subgroup Ia } \\
\text { (normal control ) }\end{array}$ & $\begin{array}{l}\text { Subgroup Ib (normal } \\
\text { obestatin treated) }\end{array}$ & $\begin{array}{l}\text { Subgroup IIa } \\
\text { (Diabetic control) }\end{array}$ & $\begin{array}{l}\text { Subgroup IIb (Diabetic } \\
\text { obestatin treated) }\end{array}$ \\
\hline MUC5AC & $0.99 \pm 0.39$ & $1.4 \pm 0.28^{\mathrm{a}^{*}}$ & $0.65 \pm 0.13^{\mathrm{ab}^{*}}$ & $0.95 \pm 0.17^{\mathrm{bc}^{*}}$ \\
\hline H+-K+ ATPase $\alpha$-subunit & $1 \pm 0.2$ & $1.3 \pm 0.3^{\mathrm{a}^{*}}$ & $0.78 \pm 0.4^{\mathrm{ab}^{*}}$ & $0.93 \pm 0.1^{\mathrm{bc}^{*}}$ \\
& & & & \\
\hline
\end{tabular}

$\left({ }^{a}\right)=$ significant vs. group Ia,$\left({ }^{b}\right)=$ significant vs. group $\mathrm{Ib},\left({ }^{\mathrm{c}}\right)=$ significant vs. group IIa 
Table 3 showed the effect of obestatin administration on serum metabolic parameters:

In subgroup $\mathrm{Ib}$ (normal obestatin treated), there was non significant change in serum glucose level, serum insulin level, in comparison with that of Subgroup IA (normal control) $(\mathrm{P}>0.05)$.

In Subgroup IIa (diabetic control) there was significant decrease in serum insulin level and significant increase in serum glucose level when compared with that of normal rats (subgroup Ia and Ib) $(\mathrm{p}<0.001)$.

In subgroup IIb (diabetic obestatin treated), there were significant increase in serum insulin and significant decrease in serum glucose levels when compared with that of subgroup IIa $(p<0.001)$, while there was significant decrease in serum insulin and significant increase in serum glucose level when compared with that subgroup Ia and subgroup Ib $(\mathrm{p}<0.001)$.

Table 3: Effect of obestatin administration on serum metabolic parameters in all studied groups

\begin{tabular}{|l|c|c|c|c|}
\hline & \multicolumn{2}{|c|}{$\begin{array}{c}\text { GROUP I } \\
\text { (NORMAL) }\end{array}$} & \multicolumn{2}{c|}{$\begin{array}{c}\text { GROUP II } \\
\text { (DIABETIC) }\end{array}$} \\
\hline & $\begin{array}{c}\text { Subgroup Ia (normal } \\
\text { control ) }\end{array}$ & $\begin{array}{c}\text { Subgroup Ib (normal } \\
\text { obestatin treated) }\end{array}$ & $\begin{array}{c}\text { Subgroup IIa (Diabetic } \\
\text { control) }\end{array}$ & $\begin{array}{c}\text { Subgroup IIb (Diabetic } \\
\text { obestatin treated) }\end{array}$ \\
\hline $\begin{array}{l}\text { Glucose } \\
(\mathrm{mg} / \mathrm{dl})\end{array}$ & $75.5 \pm 2.53$ & $73.87 \pm 2.90$ & $453.7 \pm 4.27^{\mathrm{ab} \mathrm{b}^{* * *}}$ & $199.37 \pm 6.97^{\mathrm{abc} * * *}$ \\
\hline $\begin{array}{l}\text { ssulin } \\
\mathrm{I} \text { IU/ml) }\end{array}$ & $8.85 \pm 0.716$ & $9.04 \pm 0.50$ & $2.17 \pm 0.18^{\mathrm{ab} \mathrm{b}^{* * *}}$ & $6.24 \pm 2.54^{\mathrm{abc} * * *}$ \\
\hline
\end{tabular}

$\left({ }^{a}\right)=$ significant vs. group Ia, $\left({ }^{b}\right)=$ significant vs. group $\mathrm{Ib},\left(^{c}\right)=$ significant vs. group IIa

\section{Discussion}

In the current study, chronic administration of obestatin increase gastric acid secretion, as it increase total acid output and increased mRNA expression of $\mathrm{H}+\mathrm{K}+\mathrm{-ATPase} \alpha$-subunit, which is an enzyme located in the apical membrane of the parietal cell and is the most critical component of the ion transport system mediating acid secretion in the stomach ${ }^{[31]}$. Many suggestions could explain this finding include, increased local ghrelin secretion as proved in the current work by a significant increase in ghrelin level in gastric secretion in obestatin treated groups. This finding can be supported by Duygu et al. ${ }^{[32]}$ who stated that the number of ghrelin immunopositive cells in fundus tissue of stomach are considerably high in obestatin treated animals for 14 days. The increased ghrelin may be the mediator of obestatin to enhance gastric acid secretion, as ghrelin has a stimulatory role in regulating gastric acid secretion ${ }^{[33]}$. Furthermore the increased ghrelin gastic level was significantly positive correlated with the decreased
$\mathrm{pH}$ in the present results. Another suggestion is the vagal stimulation, as obestatin was co-localized with acetylcholine in the myenteric plexus of the gastrointestinal (GI) tract ${ }^{[34]}$, suggesting a role of obestatin in regulating GI tract via the cholinergic system ${ }^{[34]}$. Importantly, Kapica et al. ${ }^{[35]}$ proved the obestatin capability of increasing the pancreatic protein output in rats via vagal activation.

It is interesting that ATP-dependent $\mathrm{K}^{+}(\mathrm{KATP})$ channels are sensitive to obestatin ${ }^{[36]}$, and its stimulatory action on insulin secretion was prevented by $\mathrm{k}$ channel openers drugs ${ }^{[37]}$. KATP channels openers were known to interfere with $\mathrm{Ca}^{++}$ ion influx and to antagonize mobilization of $\mathrm{Ca}^{++}$ bound to intracellular stores leading to reduction in free cytosolic $\mathrm{Ca}^{++}$ion which is important for gastric acid and pepsin secretion ${ }^{[38]}$. So it can be hypothesized that closure of KATP channels is one of obestatin tools to stimulate gastric secretion.

Adrenal cortex may have an indirect role in the obestatin effect on gastric secretion, as obestatin acts through corticotrophin receptors (type I and II) and activated corticotrophin releasing hormone (CRH)-neurons in the hypothalamus, ${ }^{[39]}$ elevating 
plasma corticosterone levels [39,40] Elevated corticosteroid level stimulate gastric glands to secrete acid and pepsin ${ }^{[41,42]}$.

Another mechanism of the stimulatory role of obestatin could be related to the inhibition of the dopamine release from rat hypothalamic ${ }^{[43]}$, as dopamine decrease the activity gastric $\mathrm{H}+\mathrm{K}+-$ ATPase in acute and chronic unpredictable stress models $^{[44]}$.

Somatostatin which is released from gastric mucosa $\mathrm{D}$ cells, decreases acid secretion by direct inhibition of parietal cells or by decreasing histamine secretion from enterochromaffin cells (ECLs) and decreasing gastrin secretion from $\mathrm{G}$ cells $^{[45,46]}$. Another explanation of obestatin action may be through affecting gastric somatostatin receptors, as obestatin reduced the expression of pituitary somatostatin receptor subtypes (sst1 and sst2) ${ }^{[40]}$, it may have the same suppressing effect on gastric sst2 receptor.

It is worth saying that obestatin increase expression of nitric oxide synthase (NOS) and endothelial nitric oxide (NO) generation [47,48]. Tsuchiya et al. ${ }^{[49]}$ have shown that centrally injected NO donor stimulated gastric acid secretion in both conscious and anesthetized rats. Furthermore, Kitay et al. ${ }^{[50]}$ reported that NO can induce acid secretion via the $\mathrm{H}+, \mathrm{K}+$ ATPase activation in resting glands, they suggest that postprandial increased levels of L-arginine in the blood can cause a continued secretion of acid from the parietal cell even in the absence of classical secretagogues.

Moreover, chronic administration of obestatin caused a significant increase in the volume of gastric secretion, this effect may be through NO production, as NO receptor antagonist markedly decreased the volume of gastric secretion ${ }^{[33]}$.

In addition, real time PCR showed increased gene expression of mucin (MUC5AC) in obestatin treated groups, MUC5AC is the major mucin in the normal stomach, secreted by the surface mucus cells, it is a main component of gastric mucus protective layer ${ }^{[51]}$, this effect may be due to the vasodilator effect of obestatin ${ }^{[52]}$, as efficient blood supply helps improvement of mucosal defense in gastric mucosa ${ }^{[53]}$. Claudia et al. ${ }^{[52]}$ stated that endothelial dependent NO/cGMP signaling. was involved in the vasodilator effect of obestatin by endothelial $\mathrm{NO}$ generation, it was reported that NO has a protective effect on the surface mucus bicarbonate barrier $^{[54]}$. NO increase mucosal prostaglandin (PG) ${ }^{[55]}$, which play a major role in preservation of gastric mucosal integrity, and ulcer healing by induction of cytoprotective bicarbonates and mucous glycoproteins ${ }^{[56]}$.

In diabetes, there is low level of NO due to oxidative stress ${ }^{[57]}$ this caused diabetic vascular problems which lead to variety of neuropathy[58]. Claudia et al. ${ }^{[52]}$ stated that obestatin increase endothelial NO generation, which is one of the most potent endogenous vasodilators, and widely recognized as an endogenous vasoprotective in diabetes ${ }^{[58]}$, by improvement of diabetic gastropathy, this may caused increase in gastric secretion in streptozotocin induced diabetic rats when compared with control diabetic rats.

In the present study, significant reduction in serum glucose level and increase in insulin level was observed in the obestatin treated diabetic rats, these findings were in agreement with that given by Granata et al ${ }^{[17]}$, who reported that obestatin counteracted all STZ-diabetic effects by reducing glucose and increasing insulin levels, this could be attributed to its role in prevention of pancreatic $\beta$ cell death and stimulation of its regeneration ${ }^{[8,59]}$, in addition, it was observed that beta cells were more responsive to obestatin when glucose levels were high which enhance insulin release ${ }^{[35,60]}$.

The significant increase in insulin levels in this study may act as indirect preservation of gastric functions, as it was reported that insulin has the ability to reverse established diabetic neuropathy ${ }^{[61]}$.

\section{Conclusion}

The present study demonstrated stimulatory effect of obestatin on gastric acid accompanied by increased mucin in both normal and STZ induced diabetic rats. This beneficial action mediated partially by increased gastric ghrelin secretion.

\section{Limitations}

In this study, we did not studied the effect of chronic obestatin treatment on gastric acid in rats with different regimes of food restriction, future studied are required . 


\section{Acknowledgment}

To Prof./Rasha Lotfy, Biochemistry Department Faculty of Medicine, Zagazig University for performing real time PCR

\section{Compliance with Ethical Standards}

Declaration of interest statement The authors declare that there is no conflict of interests regarding the publication of this paper

\section{Ethical approval}

All animals received care according to the guide and ethical regulations for the care and use of laboratory animals according to Institute of Laboratory Animal Resources, all experimental procedures were approved and in accordance with the ethical standards of the Institutional Research Board of Zagazig University.

\section{References}

1 Zhang JV, Jahr H, Luo CW, Klein C, Van Kolen K, Ver Donck L, De A, Baart E, Li J, Moechars D, Hsueh AJ. Obestatin induction of early-response gene expression in gastrointestinal and adipose tissues and the mediatory role of $\mathrm{G}$ protein-coupled receptor, GPR39. Mol Endocrinol 2008; 22(6): 14641475 DOI: $10.1210 / \mathrm{me} .2007-0569$

2 Chartrel N, Alvear-Perez R, Leprince J, Iturrioz X, Reaux-Le Goazigo A, Audinot V, Chomarat P, Coge F, Nosjean O, Rodriguez M, Galizzi JP, Boutin JA, Vaudry H, LlorensCortes C. Comment on "Obestatin, a peptide encoded by the ghrelin gene, opposes ghrelin's effects on food intake". Science 2007; 315(5813): 766; author reply 766 DOI: 10.1126/science. 1135047

3 Van Dijck A, Van Dam D, Vergote V, De Spiegeleer B, Luyten W, Schoofs L, De Deyn PP. Central administration of obestatin fails to show inhibitory effects on food and water intake in mice. Regul Pept 2009; 156(1-3): 7782 DOI: $\underline{10.1016 / \text { i.regpep.2009.04.014 }}$

4 Gourcerol G, St-Pierre DH, Tache Y. Lack of obestatin effects on food intake: should obestatin be renamed ghrelin-associated peptide (GAP)? Regul Pept 2007; 141(1-3): 17 DOI: $10.1016 /$ j.regpep.2006.12.023

5 Hassouna R, Zizzari P, Tolle V. The ghrelin/obestatin balance in the physiological and pathological control of growth hormone secretion, body composition and food intake. $\boldsymbol{J}$ Neuroendocrinol 2010; 22(7): 793-804 DOI: 10.1111/j.1365-2826.2010.02019.x

6 Slupecka M, Wolinski J, Herman AP, Ochniewicz P, Kornacka MK. [Biological role of obestatin in physiology and pathophysiology]. Med Wieku Rozwoj 2012; 16(1): 47-52 [PMID: 22516773]

7 Aboufard, G.M.; Madi, N.M.; Abo zade, A.A. Circulating obestatin level in diabetic and obese rats. Tanta Med J.,2014, 42 (1), 1-5.

8 Granata R, Gallo D, Luque RM, Baragli A, Scarlatti F, Grande C, Gesmundo I, CordobaChacon J, Bergandi L, Settanni F, Togliatto G, Volante M, Garetto S, Annunziata M, Chanclon B, Gargantini E, Rocchietto S, Matera L, Datta G, Morino M, Brizzi MF, Ong H, Camussi G, Castano JP, Papotti M, Ghigo E. Obestatin regulates adipocyte function and protects against diet-induced insulin resistance and inflammation. FASEB J 2012; 26(8): 3393-3411 DOI: 10.1096/fj.11-201343

9 Pradhan G, Wu CS, Han Lee J, Kanikarla P, Guo S, Yechoor VK, Samson SL, Sun Y. Obestatin stimulates glucose-induced insulin secretion through ghrelin receptor GHS-R. Sci $\boldsymbol{R e p} 2017$; 7(1): 979 DOI: 10.1038/s41598017-00888-0

10 Zhao CM, Furnes MW, Stenstrom B, Kulseng B, Chen D. Characterization of obestatin- and ghrelin-producing cells in the gastrointestinal tract and pancreas of rats: an immunohistochemical and electronmicroscopic study. Cell Tissue Res 2008; 331(3): 575-587 DOI: $10.1007 / \mathrm{s} 00441-007-$ 0514-3

11 Mizutani M, Atsuchi K, Asakawa A, Matsuda N, Fujimura M, Inui A, Kato I, Fujimiya M. Localization of acyl ghrelin- and des-acyl ghrelin-immunoreactive cells in the rat stomach and their responses to intragastric $\mathrm{pH}$. Am J Physiol Gastrointest Liver Physiol 2009; 
297(5): $\quad$ G974-980

10.1152/ajpgi.00147.2009

12 Egerod KL, Holst B, Petersen PS, Hansen JB, Mulder J, Hokfelt T, Schwartz TW. GPR39 splice variants versus antisense gene LYPD1: expression and regulation in gastrointestinal tract, endocrine pancreas, liver, and white adipose tissue. Mol Endocrinol 2007; 21(7): 1685-1698 DOI: 10.1210/me.2007-0055

13 Nakamura $T$, Takebe $K$, Imamura $K$, Miyazawa T, Ishii M, Kudoh K, Terada A, Machida K, Kikuchi H, Kasai F, et al. Decreased gastric secretory functions in diabetic patients with autonomic neuropathy. Tohoku J Exp Med 1994; 173(2): 199-208

14 Perez-Vilar J, Mabolo R. Gel-forming mucins. Notions from in vitro studies. Histol Histopathol 2007; 22(4): 455-464 DOI: 10.14670/HH-22.455

15 Chen X, Fu XS, Li CP, Zhao HX. ER stress and ER stress-induced apoptosis are activated in gastric SMCs in diabetic rats. World $J$ Gastroenterol 2014; 20(25): 8260-8267 DOI: 10.3748/wjg.v20.i25.8260

16 Wang N, Siu F, Zhang Y. Effect of astragaloside IV on diabetic gastric mucosa in vivo and in vitro. Am J Transl Res 2017; 9(11): 4902-4913

17 Granata R, Volante M, Settanni F, Gauna C, Ghe C, Annunziata M, Deidda B, Gesmundo I, Abribat T, van der Lely AJ, Muccioli G, Ghigo E, Papotti M. Unacylated ghrelin and obestatin increase islet cell mass and prevent diabetes in streptozotocin-treated newborn rats. $\boldsymbol{J} \mathbf{M o l}$ Endocrinol 2010; 45(1): 9-17 DOI: 10.1677/JME-09-0141

18 Li ZF, Guo ZF, Cao J, Hu JQ, Zhao XX, Xu RL, Huang XM, Qin YW, Zheng X. Plasma ghrelin and obestatin levels are increased in spontaneously hypertensive rats. Peptides 2010; 31(2): 297-300 DOI: 10.1016/j.peptides.2009.11.018

19 Institute of laboratory animal resources. Commission on life sciences and National research council: Guide for the care and use of laboratory animals, 8th Edition. Pbl: National academy press, 1996, Washington DC, 21-55

20 Jahan, S.; Sidrat, T.; Ahmed, S.; Wazir, H. Effect of obestatin on morphometry of testes and testosterone secretion in male rats. $\boldsymbol{A} \boldsymbol{f r} \boldsymbol{J}$

Biotech., 2011, 10 (39), 7717-7722

21 Cam M, Yavuz O, Guven A, Ercan F, Bukan N, Ustundag N. Protective effects of chronic melatonin treatment against renal injury in streptozotocin-induced diabetic rats. J Pineal Res 2003; 35(3): 212-220 [PMID: 12932206]

22 Chen, H. C.; Guh, J. Y.; Chang, J .M.; Hsieh, M. $\mathrm{C}$ role of lipid control in diabetic nephropathy. kidey int.,2005, 67(94), 60-62.

23 Lin YY, Tseng TJ, Hsieh YL, Luo KR, Lin WM, Chiang H, Hsieh ST. Depletion of peptidergic innervation in the gastric mucosa of streptozotocin-induced diabetic rats. $\operatorname{Exp}$ Neurol 2008; 213(2): 388-396 DOI: 10.1016/j.expneurol.2008.07.001

24 Alumets J, Ekelund M, Hakanson R, Hedenbro J, Rehfeld JF, Sundler F, Vallgren S. Gastric acid response to pylorus ligation in rats: is gastrin or histamine involved? J Physiol 1982; 323: $145-156$

25 Mulholland MW, Debas HT. Cholecystokinin receptor antagonism of stimulated pancreatic and gastric secretion. J Surg Res 1989; 47(5): 460-464 [PMID: 2478762]

26 Abd El Motteleb,D.M.; Hasan, M.M. Gastroprotective effect of simvastatin against experimentally induced gastric ulcers in rats: Role of ATP-sensitive $\mathrm{K}+$ channels. $\boldsymbol{J} \mathbf{A m}$ Sci.,2011, 7(7).

27 Kojima M, Hosoda H, Date Y, Nakazato M, Matsuo H, Kangawa K. Ghrelin is a growthhormone-releasing acylated peptide from stomach. Nature 1999; 402(6762): 656-660 [PMID: 10604470 DOI: 10.1038/45230]

28 Wallace JL, Vong L, Dharmani P, Srivastava V, Chadee K. Muc-2-deficient mice display a sex-specific, COX-2-related impairment of gastric mucosal repair. Am J Pathol 2011; 178(3): 1126-1133 DOI: 10.1016/j.ajpath.2010.11.048

29 Tietz, N.W.; Cook, T.; McNiven, M.A. Clinical Guide to Laboratory Tests, W.B. Saunders, Co., 1995, Philadelphia, 509-512.

30 Temple R, Clark PM, Hales CN. Measurement of insulin secretion in type 2 diabetes: problems and pitfalls. Diabet Med 1992; 9(6): 503-512 [PMID: 1643797] 
31 Abe K, Tani K, Nishizawa T, Fujiyoshi Y. Inter-subunit interaction of gastric $\mathrm{H}+, \mathrm{K}+-$ ATPase prevents reverse reaction of the transport cycle. $\boldsymbol{E M B O} \boldsymbol{J}$ 2009; 28(11): 1637 1643 DOI: $10.1038 /$ emboj.2009.102

32 Udum D, Belenli D, Ilhan T, Gunes N, Sonat F, Yalcin M. Obestatin and Ghrelin May Have a Complementary Function During Acute and Chronic Period in Mice. Protein Pept Lett 2016; 23(4): 349-357 [PMID: 26845768]

33 Bilgin HM, Tumer C, Diken $\mathrm{H}$, Kelle $\mathrm{M}$, Sermet A. Role of ghrelin in the regulation of gastric acid secretion involving nitrergic mechanisms in rats. Physiol Res 2008; 57(4): 563-568 [PMID: 17705669]

34 Dun SL, Brailoiu GC, Brailoiu E, Yang J, Chang JK, Dun NJ. Distribution and biological activity of obestatin in the rat. $\boldsymbol{J}$ Endocrinol 2006; 191(2): 481-489 DOI: 10.1677/joe.1.06944

35 Kapica M, Zabielska M, Puzio I, Jankowska A, Kato I, Kuwahara A, Zabielski R. Obestatin stimulates the secretion of pancreatic juice enzymes through a vagal pathway in anaesthetized rats - preliminary results. $\boldsymbol{J}$ Physiol Pharmacol 2007; 58 Suppl 3: 123-130 [PMID: 17901588]

36 Egido EM, Hernandez R, Marco J, Silvestre RA. Effect of obestatin on insulin, glucagon and somatostatin secretion in the perfused rat pancreas. Regul Pept 2009; 152(1-3): 61-66 DOI: $10.1016 /$ j.regpep.2008.08.003

37 Gesmundo I, Gallo D, Favaro E, Ghigo E, Granata R. Obestatin: a new metabolic player in the pancreas and white adipose tissue. IUBMB Life 2013; 65(12): 976-982 [PMID: 24217898 DOI: 10.1002/iub.1226]

38 Bose M, Motghare VM, Dakhale GN, Turankar AV. Antiulcer activity of levcromakalim and nicorandil in albino rats: a comparative study. Pol J Pharmacol 2003; 55(1): 91-95 [PMID: 12856831]

39 Szakács, J.; Szabó, G. Study of the effects of the ghrelin-associated peptide obestatin on stress-related behaviors. University of Szeged. Available via, http://doktori.bibl.uszeged.hu/4020/3/Szakacs_Julia_tezis_angol.p $\underline{\text { df,2017 }}$
40 Luque RM, Cordoba-Chacon J, Ibanez-Costa A, Gesmundo I, Grande C, Gracia-Navarro F, Tena-Sempere M, Ghigo E, Gahete MD, Granata R, Kineman RD, Castano JP. Obestatin plays an opposite role in the regulation of pituitary somatotrope and corticotrope function in female primates and male/female mice. Endocrinology 2014; 155(4): 1407-1417 DOI: 10.1210/en.20131728

41 Yigiter M, Albayrak Y, Polat B, Suleyman B, Salman AB, Suleyman H. Influence of adrenal hormones in the occurrence and prevention of stress ulcers. J Pediatr Surg 2010; 45(11): 2154-2159 [PMID: 21034937 DOI: 10.1016/j.jpedsurg.2010.07.027]

42 Fink G. Stress controversies: post-traumatic stress disorder, hippocampal volume, gastroduodenal ulceration*. $\boldsymbol{J}$ Neuroendocrinol 2011; 23(2): 107-117 DOI: 10.1111/j.1365-2826.2010.02089.x

43 Brunetti L, Di Nisio C, Recinella L, Orlando G, Ferrante C, Chiavaroli A, Leone S, Di Michele P, Shohreh R, Vacca M. Obestatin inhibits dopamine release in rat hypothalamus. Eur $\boldsymbol{J}$ Pharmacol 2010; 641(2-3): 142-147 [PMID: 20553917 DOI: $10.1016 /$ j.ejphar.2010.05.059]

44 Rasheed N, Alghasham A. Central dopaminergic system and its implications in stress-mediated neurological disorders and gastric ulcers: short review. Adv Pharmacol Sci 2012; 2012: 182671 DOI: 10.1155/2012/182671

45 Schubert,M..L.Gastric exocrine and endocrine secretion. Curr Opin Gastroenterol., 2009, 25(6), 529-536

46 Waldum, H. L.; Qvigstad, G.; Fossmark, R. Rebound acid secretion from a physiologic, pathophysiological and clinical viewpoint. Scandinavian J Gastroenterol.,2010, 45(4),389-394.

47 Agnew AJ, Robinson E, McVicar CM, Harvey AP, Ali IH, Lindsay JE, McDonald DM, Green BD, Grieve DJ. The gastrointestinal peptide obestatin induces vascular relaxation via specific activation of endothelium-dependent NO signalling. Br J Pharmacol 2012; 166(1): 327-338 DOI: $\quad \underline{10.1111 / j .1476-}$ 5381.2011.01761.x 
$48 \mathrm{Ku}$ JM, Andrews ZB, Barsby T, Reichenbach A, Lemus MB, Drummond GR, Sleeman MW, Spencer SJ, Sobey CG, Miller AA. Ghrelinrelated peptides exert protective effects in the cerebral circulation of male mice through a nonclassical ghrelin receptor(s). Endocrinology 2015; 156(1): 280-290 DOI: 10.1210/en.2014-1415

49 Tsuchiya S, Horie S, Watanabe K. Stimulatory effects of centrally injected nitric oxide donors on gastric acid secretion in anesthetized rats. Jpn J Pharmacol 2002; 89(2): 126-132 [PMID: 12120754]

50 Kitay AM, Link A, Geibel JP. Activation of Secretagogue Independent Gastric Acid Secretion via Endothelial Nitric Oxide Synthase Stimulation in Rats. Cell Physiol Biochem 2017; 44(4): 1606-1615 [PMID: 29212068 DOI: 10.1159/000485755]

51 Squire JM, Guerreiro MJ, Sidebotham RL, Reis CA, Wiseman J, Luther PK. Quantitative MUC5AC and MUC6 mucin estimations in gastric mucus by a least-squares minimization method. Anal Biochem 2013; 439(2): 204-211 DOI: $10.1016 /$ j.ab.2013.04.013

52 Penna C, Tullio F, Femmino S, Rocca C, Angelone T, Cerra MC, Gallo MP, Gesmundo I, Fanciulli A, Brizzi MF, Pagliaro P, Alloatti G, Granata R. Obestatin regulates cardiovascular function and promotes cardioprotection through the nitric oxide pathway. J Cell Mol Med 2017; 21(12): 36703678 DOI: $10.1111 / \mathrm{jcmm} .13277$

53 Konturek PC, Konturek SJ. The history of gastrointestinal hormones and the Polish contribution to elucidation of their biology and relation to nervous system. $J$ Physiol Pharmacol 2003; 54 Suppl 3: 83-98 [PMID: 15075466]

54 Moura Rocha NF, Venancio ET, Moura BA, Gomes Silva MI, Aquino Neto MR, Vasconcelos Rios ER, de Sousa DP, Mendes Vasconcelos SM, de Franca Fonteles MM, de Sousa FC. Gastroprotection of (-)-alphabisabolol on acute gastric mucosal lesions in mice: the possible involved pharmacological mechanisms. Fundam Clin Pharmacol 2010; 24(1): 63-71 DOI: $\underline{10.1111 / j .1472-}$ 8206.2009.00726.x
55 Mollace V, Muscoli C, Masini E, Cuzzocrea S, Salvemini D. Modulation of prostaglandin biosynthesis by nitric oxide and nitric oxide donors. Pharmacol Rev 2005; 57(2): 217-252 [PMID: 15914468 DOI: 10.1124/pr.57.2.1]

56 Silva MI, Moura BA, Neto MR, Tome Ada R, Rocha NF, de Carvalho AM, Macedo DS, Vasconcelos SM, de Sousa DP, Viana GS, de Sousa FC. Gastroprotective activity of isopulegol on experimentally induced gastric lesions in mice: investigation of possible mechanisms of action. Naunyn Schmiedebergs Arch Pharmacol 2009; 380(3): 233-245 DOI: $10.1007 / \mathrm{s} 00210-009-0429-5$

57 Beltowski J, Kedra A. Asymmetric dimethylarginine (ADMA) as a target for pharmacotherapy. Pharmacol Rep 2006; 58(2): 159-178 [PMID: 16702618]

58 Groop PH, Forsblom C, Thomas MC. Mechanisms of disease: Pathway-selective insulin resistance and microvascular complications of diabetes. Nat Clin Pract Endocrinol Metab 2005; 1(2): 100-110 DOI: 10.1038/ncpendmet0046

59 Baragli A, Grande C, Gesmundo I, Settanni F, Taliano M, Gallo D, Gargantini E, Ghigo E, Granata R. Obestatin enhances in vitro generation of pancreatic islets through regulation of developmental pathways. PLoS One 2013; 8(5): e64374 DOI: 10.1371/journal.pone.0064374

60 Seim I, Walpole C, Amorim L, Josh P, Herington A, Chopin L. The expanding roles of the ghrelin-gene derived peptide obestatin in health and disease. Mol Cell Endocrinol 2011; 340(1): 111-117 [PMID: 21459124 DOI: 10.1016/j.mce.2011.03.018]

61 Robert, E.S.; Feng, D.; Wang, Q. Effect of Insulin and an Erythropoietin-Derived Peptide (ARA290) on Established Neuritic Dystrophy and Neuronopathy in Akita (Ins2Akita) Diabetic Mouse Sympathetic Ganglia. Exp. Neurol., 2011 232(2), 126-135. 